\title{
PERAN KOPERASI DALAM PEMBERDAYAAN PETANI KOPI DI KABUPATEN MANDAILING NATAL
}

\section{The Role of Cooperation in Empowerment of Coffee Farmers in Mandailing Natal District}

\author{
Yuliana Kansrini $^{1}$, Amelia Zuliyanti ${ }^{2}$, Puji Wahyu Mulyani ${ }^{3}$, dan Darbi Pirmansyah ${ }^{4}$ \\ ${ }^{1,3,4}$ Politeknik Pembangunan Pertanian Medan, Jl Binjai Km 10, Medan, 20002, Indonesia \\ ${ }^{2}$ Universitas Sumatera Utara, Jl.Dr.A.Sof y an No 3, Medan, 201 55, Indonesia \\ *email koresponden: puji.wahyu101@ gmail.com
}

\begin{abstract}
Abstrak
Kopera si Mandailing Jaya sebagai kelembagaan petani kopi yang mendukung a gribisnis kopi di Kecamatan Ulu Pungkut Kabupaten Mandailing Na tal. Pentingnya keberadaan Koperasi Mandailing Ja ya dapat m enye barlu askan in formasi tentang u saha kopi, membantu pemasaran, memberikan pelatihan dan melakukan pemberda yaan pe tani kopi. Tujuan penelitian ini untuk mengetahui peran koperasi dalam pemberdayaan petani kopi, da n m en getahui pen garuh peran koperasi dalam pemberdayaan petani kopi. Pemilihan lokasi secara sengaja (purposive) di Keca matan Ulu Pungkut Kabupaten Mandailing Natal. Metode penelitian a dalah deskriptif kuantitatif menggunakan analisis regre si line a r da $\mathrm{n}$ variabel yang digunakan a dalah peran koperasi (mitra usaha, pemberi pelatihan, fasilit a tor pemasaran, fasilitator permodalan, dan motivator) dan pemberdayaan (penggalian potensi, penguatan, pemandirian). Pen gambilan populasi secara sengaja (purposive), sampel secara sensus adalah petanikopisebanyak 43 orang. Teknik pengumpula $\mathrm{n} d$ ata dilakukan dengan cara observasi, wa wancara, dan kuesioner. Hasil penelitian menunjukkan bahwa peran koperasi sebagai mitra usaha, pemberi pelatihan, fasilitator pemasaran, fasilitator permodalan, dan motivator terma suk ka tegori sedang yakni 52,9 persen dalam pemberdayaan petani kopi. Secara statistik, hasil a nalisis regresi peran k o pera si berpe nga ruh signifikan terhadap pemberdayaan petani kopi. Koperasi dapat berperan optimal, diperlukan pengua tan kelembagaan Kopera si Mandailing Jaya a gar koperasi dapat melakukan pemberdayaan kepada petanikopi di Kecamatan Ulu Pu ngk ut Kabupaten Mandailing Na tal..
\end{abstract}

Kata kunci: Perankoperasi, pemberdayaan petani, a gribisnis kopi

\begin{abstract}
Mandailing Jaya Cooperative as the coffee farmer institutions that supports coffee agribusiness in Ulu Pungkut District, Mandailing Natal Regency.The importance of the existence of the Mandailing Jaya Cooperative can disseminate information about the coffee business, help with marketing, provide training and conductempowerment of coffeefarmers. The purpose of this study was to determine the role of cooperatives in empowering coffee farmers, and to determine the effect of the role of cooperatives in empowering coffeefarmers. The location selection was purposively in Ulu Pungkut District, Mandailing Natal Regency. The research method is descriptive quantitative using linear regression analysis and the variables used are the role of cooperatives (business partners, training providers, market ing facilitators, capital facilitators, and motivators) and empowerment (potential exploration, strengthening, independence). The population was purposive, a census sample of 43 coffeefarmers. Data collection techniques were carried out by means of observation, interviews, and questionnaires. The results showed that the role of cooperatives as business partners, training providers, marketing facilitators, capital facilitators, and motivators was considered to have include the medium category, na mely 52.9 percent in efforts to empower coffeefarmers. Statistically, the results of the regression analysis show that the role of cooperatives has a significant effect on the empowerment of coffee farmers. Cooperatives can play an optimal ro le, it is necessary to strengthen the Mandailing Jaya Cooperative so that the cooperative can empower coffee farmers in Ulu Pungkut District, Mandailing Natal Regency.
\end{abstract}

Keywords : The Role of cooperatives, empowerment offarmers, coffee agribusiness 



\section{PENDAHULUAN}

Indonesia merupakan salah satu negara yang terkenal sebagai sentra produsen kopi terbesar ke empat di dunia. Volume kopi yang diproduksi dapat mencapai angka 739 ribu ton, dan produksi kopi dengan angka tertinggi dipegang oleh Negara Brazil mencapai lebih dari 3 juta ton (ICO, 2017). Kopi arabika dan robusta dari Provinsi Sumatera Utara memiliki reputasi yang cukup bagus di dunia Internasional dan yang paling terkenal adalah Mandheling Cofee dan Lintong Cofee. Saat ini, kopi asal Sumatera Utara yang sudah mendapatkan sertifikasi Indeks Geografis diantaranya, ada arabika Simalungun, Mandailing, Sipirok, Samosir, Lintong, dan Karo, serta ada kopi robusta dari Kabupaten Dairi (Direktorat Jendral Kekayaan Intelektual Kementerian Hukum dan HAM RI, 2016).

Kopi Arabika Mandailing berasal dari dataran tinggi Kabupaten Mandailing Natal Provinsi Sumatera Utara yang tumbuh dan berkembang sekitaran bukit barisan dengan ciri tanah vulkanis dengan iklim yang khas sehingga menghasilkan cita rasa yang unik dan merupakan salah satu jenis kopi yang banyak diminati oleh konsumen, akan tetapi petani kopi Mandailing belum merasakan manfaat dalam rantai nilai secara optimal. Salah satu kecamatan dengan potensi unggulan komoditi kopi adalah Kecamatan Ulu Pungkut berdasarkan analisis Location Quotient (LQ) teknik analisis komoditas unggulan tingkat Kecamatan di KabupatenMandailing Natal, diperoleh hasil bahwa Kecamatan Ulu Pungkut merupakan salah satu daerah dengan skor LQ tertinggi mencapai skor 18,99 untuk kopi robusta dan 19,30 untuk Arabika, artinya memiliki potensi yang besar sebagai daerah penghasil produksi kopi Mandailing jika dibandingkan dengan kecamatan lainnya (Dinas Pertanian Kabupaten Mandailing Natal, 2015).

Pengembangan Agribisnis kopi di Kecamatan Ulu Pungkut Kabupaten Mandailing Natal memiliki beberapa permasalahan dan berpengaruh terhadap produktivitas serta kesejahteraan petani. Hasil penelitian terdahulu menurut (Purba, Bakti, \& Sitepu
, 2015. ) terdapat lima faktor internal yang mempengaruhi pengembangan ekspor kopi Arabika Mandailing yaitu : 1) Kondisi fisik dan mutu biji kopi Arabika Sumatera Utara, 2) Jumlah modal yang dimiliki eksportir, 3) Potensi eksportir dalam menjangkau negara impor, 4) Waktu pengiriman kopi Arabika Sumatera Utara, 5) Promosi kopi Arabika Sumatera Utara yang dilakukan eksportir dan tujuh faktor eksternal yang mempengaruhi pengembangan ekspor kopi Arabika Sumatera Utara yaitu : 1) Permintaan kopi Sumatera Utara, 2) Adanya pesaing dari negara produsen kopi Arabika lain, 3) Peranan pemerintah dalam mendukung kegiatan ekspor, 4) Adanya konsumen tetap yang mengkonsumsi kopi Arabika Sumatera Utara, 5) Adanya surat izin untuk melakukan kegiatan ekspor, 6) Penetapan tarif ekspor dan 7) Harga jual kopi Arabika Sumatera Utara. Selanjutnya, berdasarkan hasil identifikasi di lapangan didapati hasil yang menyatakan bahwa tingginya permintaan akan komoditi kopi Mandailing, namun produktivitasnya belum optimal dan harga jual di tingkat petani cukup rendah, kebanyakan petani mengalami permasalahan dalam hal pemasaran dimana rata-rata petani kopi umumnya menjual kepada pedagang pengumpul dan harga jual mutlak ditentukan oleh pedagang pengumpul sehingga menekan harga jual dari petani.

Terbentuknya Koperasi Mandailing Jaya diharapkan dapat mengatasi permasalahan petani dalam mengelola agribisnis kopi di Kecamatan Ulu Pungkut. Koperasi Mandailing Jaya berperan sebagai media pemasaran, pemberi informasi, pengada pelatihan dan dapat memberdayakan petani hingga mencapai kemandirian. Permasalahan penelitian ini adalah: bagaimana peran Koperasi Mandailing Jaya dalam upaya pemberdayaan petani kopi di Kecamatan Ulu Pungkut, dan bagaimana pengaruh peran Koperasi Mandailing Jaya dalam upaya pemberdayaan petani kopi di Kecamatan Ulu Pungkut Kabupaten Mandailing Natal. Berdasarkan rumusan masalah tersebut, maka penelitian ini bertujuan untuk mengetahui peran Koperasi Mandailing Jaya dalam melakukan pemberdayaan petani kopi, dan untuk mengetahui pengaruh peran 
koperasi dalam upaya pemberdayaan petani kopi di Kecamatan Ulu Pungkut Kabupaten Mandailing Natal.

\section{METODE PENELITIAN}

Metode penelitian adalah deskriptif dengan pendekatan kuantitatif menggunakan analisis regresi linear dan variabel yang digunakan adalah peran koperasi (mitra usaha, pemberi pelatihan, fasilitator pemasaran, fasilitator permodalan, dan motivator) dan pemberdayaan (penggalian potensi, penguatan, pemandirian). Pengambilan populasi dalam pengkajian secara sengaja (purposive), dengan sampel secara sensus adalah petani kopi anggota Koperasi Mandailing Jaya sebanyak 43 orang. Teknik pengumpulan data dilakukan dengan cara observasi, wawancara, dan penyebaran kuesioner.

Kuesioner berisi pertanyaan-pertanyaan yang relevan dengan variabel yang diamati, untuk Peran Koperasi diukur berdasarkan antara lain: (1) mitra usaha (pengembangan usaha tani, peningkatan produktivitas, peningkatan taraf ekonomi, Instrumen penelitian digunakan untuk melakukan pengukuran dengan tujuan menghasilkan data kuantitatif yang akurat, maka setiap instrumen harus memiliki skala (Sugiyono, Metode Penelitian Kuantitatif, Kualitatif dan R\&D, 2016). Skala yang digunakan dalam pengkajian ini adalah skala likert. Skala likert digunakan untuk mengukur sikap, pendapat, dan persepsi seseorang tentang kejadian atau gejala sosial (Riduwan \& Sunarto, 2014).

Untuk mengetahui peran Koperasi Mandailing Jaya dalam pemberdayaan petani kopi dilakukan melalui skoring menggunakan skala Likert. Total skor yang diperoleh dari variabel y dapat diukur bagaimana tingkat peranan koperasi dalam upaya pemberdayaan petani kopi Untuk mengetahui tingkat $(\mathrm{N})$ dapat mengetahui rumus dibawah ini (Riduwan \& Sunarto, 2014). Kuesioner berisi pertanyaan-pertanyaan yang relevan dengan variabel yang diamati, untuk Peran Koperasi diukur berdasarkan antara lain: (1) mitra usaha (pengembangan usaha tani, peningkatan produktivitas, peningkatan taraf ekonomi, pemanfaatan peluang), (2) pemberi pelatihan (pelatihan pengembangan sdm, pelatihan keterampilan budidaya, pelatihan keterampilan pasca panen, pelatihan pemasaran), (3) fasilitator pemasaran (menampung hasil produk kopi, jejaring pemasaran, promosi produk, ikut serta dalam kegiatan pameran, (4) fasilitator permodalan (kemudahan dalam memberi pinjaman modal usaha, pemilihan pembiayaan modal, akses informasi, pelatihan pembukuan keuangan usahatani, manajemen keuangan), (5) motivator (akses informasi, pemecahan masalah, masukan, strategi pengembangan usaha). Untuk variabel pemberdayaan diukur berdasarkan: (1) penggalian potensi (optimalisasi pengembangan usaha, Peningkatan kualitas SDA dan SDM, pemberdayaan dalam melakukan usaha tani), (2) penguatan petani (pengembangan kemampuan usaha, dapat memecahkan masalah, menumbuhkan kepercayaan dalam berwirausaha, penguatan kelembagaan), (3) pemandirian (mengatasi masalah sendiri, pengembangan usaha mandiri, konsistensi berwirausaha).

Instrumen penelitian digunakan untuk melakukan pengukuran dengan tujuan menghasilkan data kuantitatif yang akurat, maka setiap instrumen harus memiliki skala (Sugiyono, MetodePenelitian Kuantitatif, Kualitatif dan R\&D, 2016). Skala yang digunakan dalam pengkajian ini adalah skala likert. Skala likert digunakan untuk mengukur sikap, pendapat, dan persepsi seseorang tentang kejadian atau gejala sosial (Riduwan dan Sunarto, 2015).

Untuk mengetahui peran Koperasi Mandailing Jaya dalam pemberdayaan petani kopi dilakukan melalui skoring menggunakan skala Likert. Total skor yang diperoleh dari variabel y dapat diukur bagaimana tingkat peranan koperasi dalam upaya pemberdayaan petani kopi Untuk mengetahui tingkat $(\mathrm{N})$ dapat mengetahui rumus dibawah ini (Riduwan \& Sunarto, 2014). 
$N=\frac{\text { Total Nilai Yang Diperoleh }}{\text { Nilai Maksimal Yang Dicapai }} \times 100 \%$

Keterangan :

$\mathrm{N}=$ Tingkat Peranan Koperasi dalam Upaya Pemberdayaan Petani Kopi yang di analasis untuk setiap variabelnya

Keterangan : Kriteria Interpretasi Skor (Riduwan dan Sunarto, 2014).

$0 \%-20 \%=$ Sangat Rendah

$21 \%-40 \%=$ Rendah

$41 \%-60 \%=$ Sedang

$61 \%-80 \%=$ Tinggi

$81 \%-100 \%=$ Sangat Tinggi

Untuk uji tingkat pengaruh peran koperasi dalam pemberdayaan petani kopi digunakan analisis regresi
X4 = Nilai X4 (Fasilitator Permodalan)

X5 = Nilai X5 (Motivator)

$\mathrm{E}=$ Error

\section{HASIL DAN PEMBAHASAN}

\section{Profil Koperasi Mandailing Jaya}

Koperasi Mandailing Jaya didirikan pada tanggal 27 September 2015 yang beralamat di Desa Alahankae Kecamatan Ulu Pungkut Kabupaten Mandailing Natal Provinsi Sumatera Utara. Koperasi Mandailing Jaya sebagai Koperasi Serba Usaha (KSU) dengan Nomor Induk Berusaha : 9120500990025. Kegiatan usaha yang dilaksanakan bentuk pengembangan koperasi saat ini yang dilaksanakan adalah usaha pembibitan dan usaha jual beli kopi dan pengolahan kopi.

Tabel 1. Hasil Pengukuran Peran Koperasi Mandailing Jaya Menurut Petani

\begin{tabular}{|c|c|c|c|c|c|}
\hline No & $\begin{array}{l}\text { Peran } \\
\text { Koperasi }\end{array}$ & Skor yang diperoleh & Skor Maksimum & Persentase (\%) & Kategori \\
\hline 1 . & Mitra Usa ha & 559 & 860 & 65,00 & Tinggi \\
\hline 2 & Pemberi Pelatihan & 358 & 860 & 41,60 & Sedang \\
\hline 3 & $\begin{array}{l}\text { Fasilita tor } \\
\text { Pemasaran }\end{array}$ & 591 & 860 & 68,70 & Tinggi \\
\hline 4 & $\begin{array}{l}\text { Fasilita tor } \\
\text { Permodalan }\end{array}$ & 269 & 860 & 31,20 & Rendah \\
\hline 5 & $\begin{array}{l}\text { Motivator } \\
\text { Total }\end{array}$ & $\begin{array}{l}496 \\
2273\end{array}$ & $\begin{array}{l}860 \\
4300\end{array}$ & $\begin{array}{l}57,70 \\
52,90\end{array}$ & $\begin{array}{l}\text { Sedang } \\
\text { Sedang }\end{array}$ \\
\hline
\end{tabular}

(Sumber: Analisis Data Primer, 2020)

dengan menggunakan Aplikasi SPSS versi 15.

Persamaan regresi yang digunakan pada penelitian ini adalah regresi linier berganda, yaitu:

$Y=\beta+\beta_{1} X_{1}+\beta_{2} X_{2}+\beta_{3} X_{3}+\beta_{4} X_{4}+\beta_{4} X_{4}+\beta_{5} X_{5}+e$

Dimana:

$\mathrm{Y}=$ Variabel terikat (Pemberdayaan Petani)

$\mathrm{B}=$ Konstanta

X1 = Nilai X1 (Mitra Usaha)

X2 = Nilai X2 (Pemberi Pelatihan)

X3 = Nilai X3( Fasilitator Pemasaran)

\section{Peran Koperasi Mandailing Jaya dalam Pemberdayaan Petani Kopi}

Pengukuran peran Koperasi Mandailing Jaya dalam pemberdayaan petani kopi di Kecamatan Ulu Pungkut dilakukan dengan cara pengukuran menggunakan skala Likert hasil penilaian 43 responden. Variabel peran dalam penelitian ini menggunakan indikator peran yaitu, peran koperasi sebagai mitra usaha, pemberi pelatihan, fasilitator pemasaran, fasilitator permodalan, dan motivator. Hasil analisis tingkat peran disajikan dalam Tabel 1. 
Berdasarkan Tabel 1 diketahui bahwa tingkat peran koperasi dalam upaya pemberdayaan petani kopi masuk dalam kriteria sedang dengan persentase sebesar 52,90 persen. Hal ini menyatakan bahwa peran Koperasi Mandailing Jaya dalam pemberdayaan petani kopi di Kecamatan Ulu Pungkut Kabupaten Mandailing Natal memberikan implikasi cukup tinggi. Hal ini sesuai dengan hasil observasi yang dilakukan di Kecamatan Ulu Pungkut dimana sebagian besar responden setuju bahwa peran koperasi dalam upaya memberdayakan petani kopi di Kecamatan Ulu Pungkut Kabupaten Mandailing Natal dinilai cukup berperan penting dan berpengaruh dalam pemberdayaan petani, karena ikut berperan serta meningkatkan taraf hidup dan perekonomian petani.

Peran koperasi tergolong tinggi pada peran sebagai fasilitator pemasaran yakni sebesar 68,70 persen dan peran koperasi sebagai mitra usaha yakni sebesar 65,00 persen. Peran sebagai fasilitator pemasaran dan mitra usaha yang telah dilakukan oleh Koperasi Mandailing Jaya dapat menjawab permasalahan petani kopi sebelum adanya kelembagaan koperasi petani kopi. Artinya, Koperasi Mandailing Jaya telah memenuhi harapan anggotanya dalam melakukan peran sebagai fasilitator pemasaran dan mitra usaha untuk pengembangan agribisnis kopi di Kecamatan Ulu Pungkut Kabupaten Mandailing Natal.

Dalam kondisi nyata secara umum yang paling tampak adalah peran koperasi dalam sebagai fasilitator pemasaran yang dinilai mampu mengangkat harga jual atau nilai tukar kopi gabah ditingkat petani sesuai dengan grade mutu hasil produksi sehingga dapat meningkatkan pendapatan dan harga jual perkilonya pernah mencapai harga Rp. 30.000,-Rp.35.000,-/kg kopi gabah, secara tidak langsung dapat memotong rantai pemasaran di tingkat tengkulak yang hanya menawarkan harga bahkan bisa mencapai selisih Rp.10.000,- jika dibandingkan dengan harga yang ditawarkan pihak koperasi.
Peran koperasi sebagai motivator dapat dilihat dari keterlibatan pihak koperasi dalam membantu dan memberitahukan petani mengenai akses informasi pasar dan berbagai pengetahuan lainnya. Selain dari pada itu pihak koperasi juga membantu dalam memecahkan masalah yang sedang dihadapi petani, memberikan masukan dan dorongan bagi petani. Beberapa perubahan pola pikir pun terjadi dari yang sebelumnya kurang mengetahui tentang budidaya menjadi lebih tahu, mulai mengenal dan memperhatikan mutu dan kualitas biji kopi yang dihasilkan dan mulai bisa mandiri dalam pelaksanaan kegaiatan usaha taninya.

Sementara itu, peran koperasi sebagai fasilitator permodalan termasuk kategori rendah yakni sebesar 31,20 persen. Petani kopi membutuhkan dukungan permodalan dalam pengembangan agribisnis kopi. Dalam hal ini, Koperasi Mandailing Jaya dapat dikatakan belum sepenuhnya mampu memfasilitasi kebutuhan permodalan bagi petani dalam pengembangan agribisnis kopi.

Koperasi Mandailing Jaya mulai dari awal pembentukan dan hingga saat ini masih merupakan koperasi yang berbentu pengembangan usaha yang biasa dikenal dengan KSU (Koperasi Serba Usaha) dan bukan basisnya permodalan. Ketetapan diawal terbentuknya koperasi serba usaha merupakan kesepakatan sebagai media untuk pengembangan usaha agribisnis perkopian di Kecamatan Ulu Pungkut Kabupaten Mandailing Natal sehingga memang benar adanya peran koperasi sebagai fasilitator permodalan belum terlaksana.

Menurut Mosher (1968) dalam (Putra \& Natsir, 2015), pertanian adalah proses produksi yang memiliki kekhasan dimana usahanya harus berhubungan dengan tanaman dan hewan. Kegiatankegiatan produksi dalam pertanian merupakan bagian dari bisnis, dimana biaya dan penerimaan merupakan hal yang utama. Proses produksi pertanian merupakan proses yang mengkombinasikan faktorfaktor produksi pertanian (input) untuk menghasilkan produksi pertanian (output). 
Sektor pertanian dalam hal ini upaya pengembangan agribisnis memiliki karakteristik yang berbeda dari sektor yang lain seperti perdagangan, jasa dan industri. Oleh sebab itu, koperasi agribisnis harus memiliki kemampuan untuk mendesain produk layanan seperti layanan permodalan usaha yang cocok untuk meningkatkan produksi anggotanya, karena sektor ini biasanya sangat dipengaruhi oleh musim dan fluktuasi harga yang tinggi. Mengingat bahwa akses permodalan menjadi faktor utama dalam mendukung pengembangan agribisnis kopi oleh petani. Oleh sebab itu, akses permodalan yang diberikan dapat memenuhi kebutuhan petani mulai dari usaha budidaya (on-farm) hingga pengolahan pasca panen (off-farm).

Disisi lain, saat ini perkembangan agribisnis kopi sangat menjanjikan. Peluang tersebut apabila dikelola dengan tepat dapat meningkatkan koperasi dan Usaha Kecil Menengah (UKM) untuk mengoptimalkan usaha agribisnis kopi (Alamsyah, 2020).

\section{Pengaruh Peran Koperasi dalam Upaya Pemberdayaan Petani Kopi}

\section{Uji Prasyarat}

\section{a.Uji Normalitas}

Hasil analisis data uji normalitas pada penelitian ini dapat dilihat pada gambar histogram dan normal $p$ - $p$ plot dengan menggunakan program SPSS for windows 15.0. pada Gambar 1 berikut.

Berdasarkan Gambar 1 dapat diketahui bahwa histogram membentuk lengkung kurve normal sehingga dapat dikatakan bahwa residual data dinyatakan normal dan asumsi normalitas terpenuhi.

Gambar 1. Histogram Uji Normalitas Data dan Normal p-p plot Data

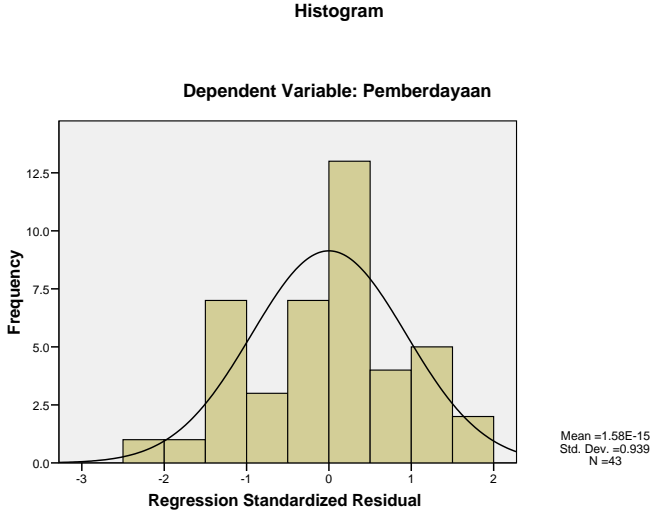

(Sumber: Analisis Da ta Primer, 2020)

pendapatan dan pada akhirnya peningkatan ekonomi bagi petani yang sekaligus dapat meningkatkan taraf perekonomian daerah. Konsumsi kopi di Indonesia memang tercatat tumbuh setiap tahunnya, yakni pada 2016 sebanyak 250 ribu ton, kemudian meningkat menjadi 335 ribu ton pada Tahun 2019. Peningkatan konsumsi kopi di Indonesia per periode 2016-2021 diprediksi tumbuh rata-rata 8,22 persen/ tahun. Perkembangan jumlah outlet usaha kopi di Indonesia juga semakin meningkat dan bertambah signifikan. Oleh sebab itu, kondisi ini menjadi potensi bagi
Normal P-P Plot of Regression Standardized Residual

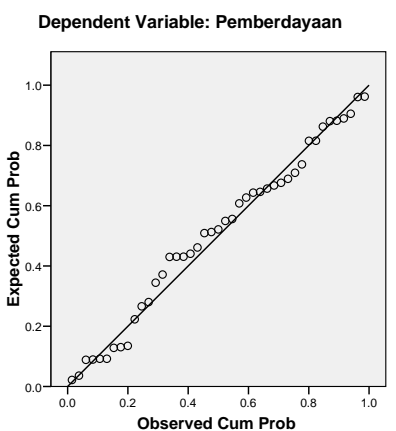

Pada gambar tersebut juga dapat dilihat bahwa plotplot diagram tersebut mengikuti alur garis lurus sehingga distribusi data dapat dikatakan normal dan memenuhi uji normalitas data. Dari hasil uji prasyarat yang sudah dilaksankan diketahui bahwa data yang digunakan memenuhi ketentuan uji normalitas dan terdistribusi secara normal. Sehing ga proses analisis data untuk mengukur pengaruh peran lembaga koperasi dalam upaya pemberdayaan petani kopi di Kecamatan Ulu Pungkut dapat dilakukan dengan metode regresi linier berganda. 


\section{b.Uji Multikolineritas}

Uji multikolinieritas bertujuan untuk menguji apakah model regresi ditemukan adanya korelasi antar variabel bebas (independen) atau tidak. Model regresi yang baik seharusnya tidak terjadi korelasi di antara vairabel independen (Ghozali, 2016). Model regresi yang bebas dari multikoliniearitas adalah model yang memiliki nilai tolerance $\geq 0,01$ atau jika nilai variance inflation factor (VIF) $\leq 10$.

Tabel 2. Hasil uji Multikolineritas

\begin{tabular}{lccll}
\hline Var & $\begin{array}{c}\text { Toler } \\
\text { ance }\end{array}$ & VIF & Kriteria & $\begin{array}{c}\text { Kesimpu } \\
\text { lan }\end{array}$ \\
\hline X1 & 0,709 & 1,409 & Tolerance & Terbebas \\
X2 & 0,943 & 1,061 & $\geq 0,1$ & a sumsi \\
X3 & 0,915 & 1,093 & VIF $\leq 10$ & multik \\
X4 & 0,671 & 1,490 & & neritas \\
X5 & 0,912 & 1,097 & & \\
\hline
\end{tabular}

Sumber: Analisis Data Primer, 2020

Berdasarkan Tabel 2 tentang hasil pengujian asumsi klasik terhadap analisis regresi linear berganda ini menunjukkan bahwa tidak menunjukkan adanya gejala multikolinieritas dimana nilai Tolerance tidak kurang dari 0,1 dan nilai VIF pada masing-masing variabel tidak lebih besar dari 10, seperti yang terlihat pada tabel 2 maka dapat disimpulkan bahwa tidak terdapat gejala multikolinieritas antara variabel-variabel bebas yang digunakan pada penelitian ini.

\section{c.Uji Heteroskedastisitas}

Uji heteroskedastisitas bertujuan untuk menguji apakah dalam model regresi terjadi ketidaksamaan variance dari residual satu pengamatan ke pengamatan yang lain Jika variance dari residual satu pengamatan ke pengamatan yang lain tetap, maka disebut homoskedastisitas dan jika berbeda disebut heteroskedastisitas. Model regresi yang baik adalah yang homoskedastisitas atau tidak terjadi heteroskedastisitas (Ghozali, 2016). Cara yang digunakan untuk mengetahui ada tidaknya heteroskedastisitas dalam penelitian ini yaitu uji glejser. Uji glejser dilakukan dengan meregresi nilai absolut residual terhadap variabel independen
(Ghozali, 2016). Jika nilai probabilitas signifikansi dari variabel independen di atas tingkat kepercay aan $5 \%(>0,05)$, maka dapat disimpulkan model regresi tidak mengandung adanya heteroskedastisitas. Adapun hasil uji heteroskedastisitas disajikan dalam Tabel 3 berikut.

Tabel 3. Hasil Uji Heteroskedastisitas

\begin{tabular}{|c|c|c|c|}
\hline Var & Sign & Kriteria & Kesimpulan \\
\hline $\mathrm{X} 1$ & 0,203 & & \\
\hline $\mathrm{X} 2$ & 0,625 & Sig & Bebas \\
\hline $\mathrm{X} 3$ & 0,429 & 0,05 & Heteroskedastisitas \\
\hline $\mathrm{X} 4$ & 0,757 & & \\
\hline X5 & 0,404 & & \\
\hline
\end{tabular}

Uji autokorelasi juga bertujuan menguji apakah dalam model regresi ada korelasi antara pengganggu pada periode- $t$ dengan kesalahan penganggu pada periode t-1 atau sebelumnya (Ghozali, 2016). Pengujian Auto Korelasi dilakukan dengan pengujian Durbin Watson dengan membandingkan nilai Durbin Watson hitung (d) dengan nilai Durbin Watson tabel, yaitu batas atas (du) dan batas bawah (dl), kriteria pengujian sebagai berikut :

a) Jika $0<\mathrm{d}<\mathrm{dl}$, maka terjadi auto korelasi positif

b) Jika d $>4$ - dl, maka terjadi autokorelasi negatif

c) Jika $\mathrm{dl}<\mathrm{d}<\mathrm{du}$, tidak ada kepastian terjadi auto korelasi atau tidak

d) Jika 4 - du $<$ d $<4$ - dl, maka tidak ada kepastian terjadi korelasi atau tidak

e) Jika du $<$ d $<4$ - du, maka tidak terjadi autokorelasi positif maupun negatif

Tabel 4. Hasil Uji Heteroskedastisitas

\begin{tabular}{lccccc}
\hline No & d & dl & du & 4-dl & 4-du \\
\hline 1 & 1,9090 & 1,2660 & 1,7794 & 2,7340 & 2,2206 \\
\hline
\end{tabular}

(Sumber: Analisis Data Primer, 2020)

Berdasarkan Tabel 4 ditambah hasil akumulasi data yang sudah disesuaikan dengan tabel Durbin Watson berdasarkan jumlah responden sebanyak 43 orang dengan 5 variabel sehingga diperoleh hasil seperti tabel diatas. Diketahui bahwa hasil yang diperoleh 
masuk dalam kriteria e, yaitu du $<\mathrm{d}<4-$ du, dengan nilai $1,7794<1,9090<2,2206$ sehingga dapat dikatakan bahwa dari hasil pengujian maka data-data tersebut tidak terjadi auto korelasi positif maupun negatif sehingga asumsi uji autokorelasi untuk melanjutkan uji regresi linier berganda terpenuhi.

\section{Uji Regresi Linier Berganda}

a. Uji Regresi Linier Berganda Pengaruh Peran Koperasi dalam Pemberdayaan Petani Kopi

Berdasarkan hasil data yang telah diperoleh dan telah dianalisis sebelumnya data hasil uji regresi linier berganda akan disajikan pada Tabel 5 . diterima. Hasil uji serempak (uji F) dapat dilihat pada tabel Anova seperti pada tabel 6 berikut ini.

Hasil analisis data Tabel 5, dapat diketahui bahwa nilai signifikannya adalah 0.000 , dimana nilai sig $(\alpha)$ $<0,05$, yang artinya $\mathrm{H}_{0}$ ditolak dan $\mathrm{H}_{1}$ diterima. Sehingga dapat diperoleh kesimpulan bahwa adanya pengaruh signifikan secara bersama-sama antara variabel bebas X1 (Mitra Usaha), X2 (Pemberi Pelatihan), X3 (Fasilitator Pemasaran), X4 (Fasilitator Permodalan), dan X5 (Motivator) terhadap variabel terikat Y (Pemberdayaan).

2. Analisis Korelasi Ganda (R)

Tabel 5. Hasil Analisis Uji Regresi Linier Berganda

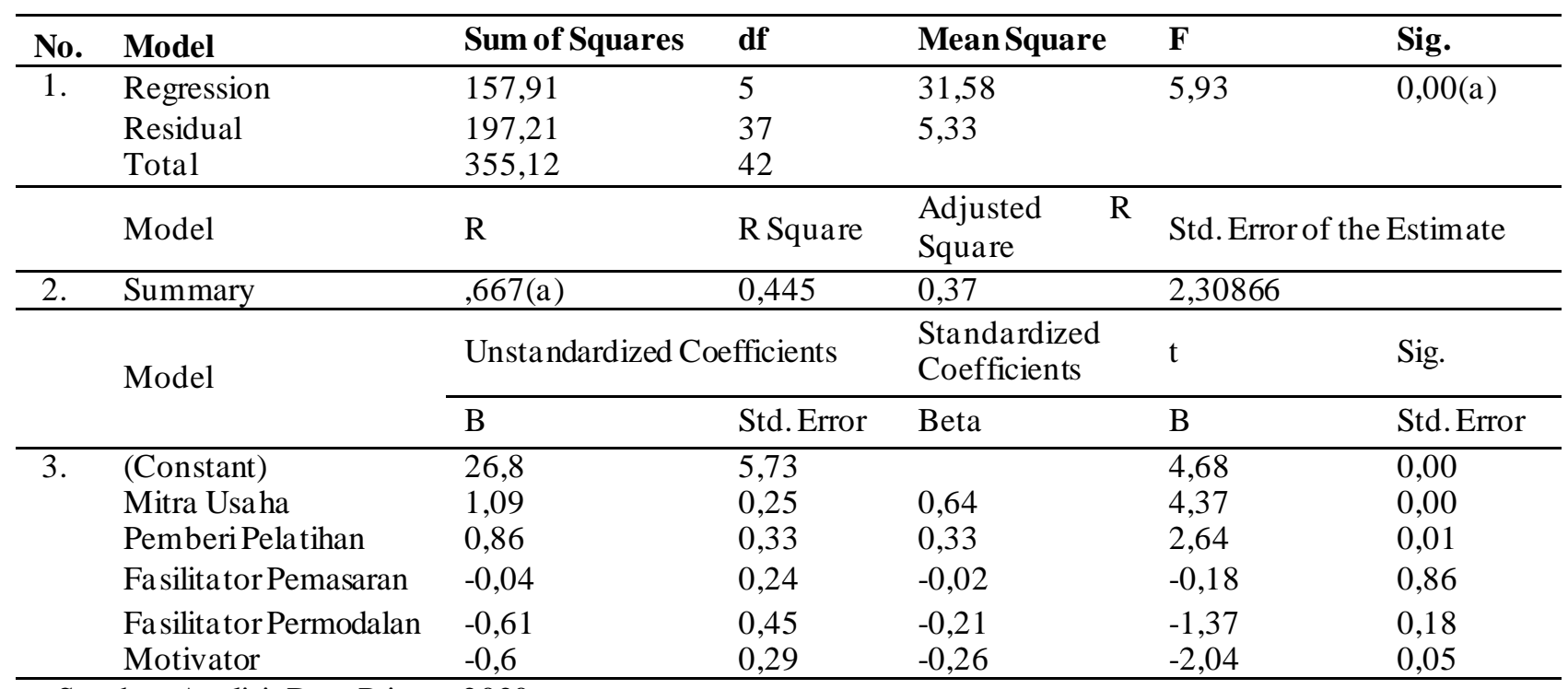

Sumber: Analisis Data Primer, 2020

\section{Uji Simultan/Serempak (F)}

Uji ini digunakan untuk mengetahui apakah variabel bebas (X1, X2, X3，X4 dan X5) secara bersamasama berpengaruh secara signifikan terhadap variabel terikat (Y). Uji ini dilakukan untuk mengetahui apakah model regresi dapat digunakan untuk memprediksi variabel terikat atau tidak. Pada uji serempak (uji F), digunakan tingkat signifikansi $(\alpha)$ sebesar 5\% atau 0.05. Adapun kriteria pengujian yaitu: 1) Jika sig > $\alpha$; maka $\mathrm{H}_{0}$ diterima dan $\mathrm{H}_{1}$ ditolak, 2) Jika sig $\leq \alpha$; maka $\mathrm{H}_{0}$ ditolak dan $\mathrm{H}_{1}$
Analisis ini digunakan untuk mengetahui hubungan antara dua atau lebih variabel bebas terhadap variabel terikat secara serentak. Koefisien ini menunjukkan seberapa besar hubungan yang terjadi antara variabel bebas secara serentak terhadap variabel terikat. Nilai R berkisar antara 0-1. Menurut (Sugiyono, 2016) pedoman untuk memberikan interpretasi koefisien korelasi sebagai berikut:

$0,00-0,199=$ Sangat Lemah

$0,20-0,399=$ Lemah 
$0,40-0,599=$ Sedang

$0,60-0,799=$ Kuat

$0,80-1,00=$ Sangat Kuat

Hasil analisis regresi, dapat dilihat pada output model summary dan disajikan pada tabel 8 diatas.

Dari hasil data analisis pada table 8 diatas diperoleh angka $R$ sebesar 0.667 . Nilai angka $R$ yang diperoleh sebesar 0.667 masuk dalam range 0,60 - 0,799 (kuat). Artinya hal ini menunjukkan bahwa adanya hubungan antara variabel bebas X1 (Mitra Usaha), X2 (Pemberi Pelatihan), X3 (Fasilitator Pemasaran), X4 (Fasilitator Permodalan), dan X 5 (Motivator) terhadap variabel terikat $\mathrm{Y}$ (Pemberdayaan) memiliki hubungan yang kuat.

\section{Analisis Determinasi $\left(\mathrm{R}^{2}\right)$}

Analisis ini digunakan untuk menunjukkan seberapa besar persentase variasi variabel bebas berpengaruh terhadap variabel terikat. Hasil analisis determinasi digambarkan dalam bentuk persentase (\%). Dari hasil analisis regresi diperoleh hasil analisis determinasi yang dapat dilihat pada Tabel 5. Cara menginterpretasikan analisis determinasi yaitu apabila angka $\mathrm{R}^{2}$ sama dengan 0 , artinya tidak ada pengaruh antara variabel bebas terhadap variabel terikat. Namun jika angka $\mathrm{R}^{2}$ sama dengan 1 , artinya pengaruh antara variabel bebas dengan variabel terikat adalah sempurna.

Berdasarkan hasil analisis determinasi pada tabel 8 , diketahui bahwa nilai $\mathrm{R}^{2}$ sebesar 0.445 atau sebesar 44,5\%. Hal ini menunjukkan bahwa variasi variabel bebas X1 (Mitra Usaha), X2 (Pemberi Pelatihan), X3 (Fasilitator Pemasaran), X4 (Fasilitator Permodalan), dan X 5 (Motivator) mampu menjelaskan sebesar $44,5 \%$ variasi terhadap variabel terikatY (Pemberdayaan). Sedangkan sisanya sebesar 55,5\% dipengaruhi atau dijelaskan oleh variabel lain yang tidak disebutkan dalam penelitian ini.

\section{Penentuan Persamaan Regresi Linier Berganda}

Penentuan Persaman dapat dilihat dari Tabel coefficient yang diperoleh dari hasil pengolahan 194 Yuliana Kansrini et.al
SPSS, dengan melihat nilai Beta untuk setiap variabel dalam pemberdayaan petani kopi.

Persamaan dari analisis regresi berganda pada penelitian sesuai dengan hasil analisis pada Tabel 5 tersebut adalah sebagai berikut:

Persamaan regresi linier berganda hasil analisis data :

$Y=a+b_{1} X_{1}+b_{2} X_{2}+b_{3} X_{3}+b_{4} X_{4}+b_{5} X_{5}+e$

$\mathrm{Y}=26,81+(1,08) \mathrm{X}_{1}+(0,85) \mathrm{X}_{2}+(-0,04) \mathrm{X}_{3}+(-$ $0,60) \mathrm{X}_{4}+(-0,59) \mathrm{X}_{5}+\mathrm{e}$.

$Y=26,81+1,08 X_{1}+0,85 X_{2}-0,04 X_{3}-0,60 X_{4}-$ $0,59 \mathrm{X}_{5}$

Keterangan:

$\mathrm{Y}=$ Pemberdayaan

$\mathrm{A}=$ Konstanta

$\mathrm{b}_{1}, \mathrm{~b}_{2}, \mathrm{~b}_{3}, \mathrm{~b}_{4}, \mathrm{~b}_{5}=$ Koefisien Regresi

X1 = Mitra Usaha

$\mathrm{X} 2=$ Pemberi Pelatihan

X3 = Fasilitator Pemasaran

$\mathrm{X} 4=$ Fasilitator Permodalan

X5 = Motivator

Berdasarkan analisis data pada Tabel 5 yang telah dilaksanakan sesuai dengan hasil yang sudah diperoleh maka persamaan regresi linier berganda yang diperoleh adalah sebagai berikut :

$Y=26,81+1,08 X_{1}+0,85 X_{2}-0,04 X_{3}-0,60 X_{4}-$ $0,59 \mathrm{X}_{5}$

Persamaan regresi diatas dapat dijelaskan sebagai berikut:

a) Konstanta sebesar 26,81, Apabila varibel X1, X2, $\mathrm{X} 3$, X4 dan $\mathrm{X} 5$ bernilai 0 , artinya nilai pemberdayaan adalah sebesar 26,81 .

b) Koefisien regresi variabel mitra usaha (X1) sebesar 1,08 artinya bahwa setiap terjadinya penambahan $1 \%$ peran sebagai mitra usaha maka proses pemberdayaan (Y) akan meningkat sebesar 1,08 . 
c) Koefisien regresi variabel pemberi pelatihan (X2) sebesar 0,85 artinya jika terjadinya penambahan $1 \%$ peran sebagai Pemberi pelatihan maka nilai pemberdayaan (Y) akan naik sebesar 0,85.

d) Koefisisen regresi variabel fasilitator pemasaran (X3) sebesar -0,04, artinya jika terjadinya penambahan $1 \%$ peran sebagai fasilitator pemasaran maka nilai pemberdayaan akan naik sebesar 0,04. Karena koefisien regresinya bernilai negatif maka dengan demikian dapat dikatakan bahwa peran sebagai fasilitator pemasaran (X3) berpengaruh negatif terhadap Nilai Pemberdayaan (Y).

e) Angka koefisien regresi variabel Fasilitator Permodalan (X4) sebesar -0,60, artinya jika variabel bebas lain nilainya tetap dan variabel X4 mengalami kenaikan $1 \%$, maka nilai pemberdayaan akan meningkat sebesar -0,60. Koefisien regresinya bernilai negatif maka dengan demikian dapat dikatakan bahwa peran sebagai fasilitator permodalan (X4) berpengaruh negatif terhadap Nilai Pemberdayaan (Y).

f) Koefisisen regresi variabel Motivator (X5) sebesar - 0,59, artirnya jika terjadi peningkatan $1 \%$ peran sebagai motivator maka nilai pemberdayaan akan meningkat sebesar -0,59. Karena koefisien regresinya bernilai negatif maka dengan demikian dapat dikatakan bahwa peran sebagai motivator (X5) berpengaruh negatif terhadap Nilai Pemberdayaan (Y).

\section{Uji Parsial (Uji T)}

Uji parsial (uji t), digunakan tingkat signifikansi $(\alpha)$ sebesar 5\% atau 0.05. Hasil uji parsial (uji t) pada program SPSS for windows 15.0 dapat dilihat pada tabel coefficient seperti pada Tabel 5.

Adapun kriteria pengujian yaitu:

Jika sig $>\alpha$; maka $\mathrm{H}_{0}$ diterima dan $\mathrm{H}_{1}$ ditolak

Jika sig $\leq \alpha$; maka $\mathrm{H}_{0}$ ditolak dan $\mathrm{H}_{1}$ diterima

Hasil analisis untuk masing-masing variabel adalah sebagai berikut :

a) Diketahui bahwa nilai signifikan variabel $\mathrm{X} 1$ (Mitra Usaha) berada pada nilai sig. 0.000, yang berarti bahwa nilai sig. $<\alpha$, sehingga $\mathrm{H}_{0}$ ditolak dan $\mathrm{H}_{1}$ diterima. Dapat disimpulkan bahwa variabel X1 (Mitra Usaha) memberikan berpengaruh secara signifikan terhadap variabel Y (Pemberdayaan) secara parsial.

Peran kemitraan yang dimaksud adalah proses bermitra dengan prinsip saling menguntungkan dua arah yang dihasilkan selama proses kegiatan usaha tani. Sebagai mitra usaha, koperasi memberikan kesempatan kepada petani agar dapat mengembangkan pengetahuan dan keterampilan untuk dapat mengatasi berbagai rintangan terkait keterbatasan dalam menggali dan mengembangkan potensi yang ada.

Model kemitraan sebagai strategi pemberdayaan, bahwa beberapa model dalam konsep pembangunan dan pengembangan dalam pemberdayaan telah bergeser dari single actor menjadi multy actor. Maksud dari kalimat tersebut adalah bahwa pemerintah yang dahulunya menjadi satu-satunya aktor yang bertanggung jawab dalam pembangunan artian pemberdayaan masyarakat kini tidak lagi dan bergerak kearah yang lebih luas serta telah melibatkan berbagai stakeholder yang dapat mendorong terjadinya proses pemberdayaan (Nurhayati \& Hadis, 2010).

b) Diketahui bahwa nilai signifikan variabel $\mathrm{X} 2$ (Pemberi Pelatihan) berada pada nilai sig. 0.012, yang berarti bahwa nilai sig. $<\alpha$, sehingga $\mathrm{H}_{0}$ ditolak dan $\mathrm{H}_{1}$ diterima. Dapat disimpulkan bahwa variabel X2 (Pemberi Pelatihan) memberikan pengaruh secara signifikan terhadap variabel Y (Pemberdayaan) secara parsial.

Peran koperasi sebagai pemberi pelatihan dalam upaya pemberdayaan berpengaruh positif dan signifikan terhadap nilai pemberdayaan. Beberapa indikator peran pemberi pelatihan yang berimplikasi cukup baik dalam nilai pemberdayaan adalah indikator mengenai pelatihan dalam akses informasi dan pemasaran serta keterampilan budidaya walaupun tidak terlaksana secara optimal berdasarkan tingkat peran yang sudah dianalisis sebelumnya. Dinyatakan berpengaruh positif dan proses beberapa pengetahuan dan keterampilan yang 
diajarkan secara tidak resmi atau terjadwal ditambah dengan peran motivator membuat pengaruh peran pemberi pelatihan menjadi berpengaruh karena memang seharusnya mendukung dalam program pemberdayaan. Berdasarkan data karakteristik proses adopsi pengetahuan dan keterampilan walau terjadi secara tidak langsung mudah diadopsi oleh petani dikarenakan dapat dilihat dari segi pendidikan banyak juga yang sudah tamat SMA dan bahkan perguruan tinggi, serta masuk dalam rentan usia yang masih sangat produktif yang didominasi usia antara 21 - 50 tahun sehingga masih mudah dalam menangkap dan memahami informasi yang diberikan.

Pelaksanaan program pemberdayaan adalah pembelajaran bagi masyarakat, sehingga bisa dikatakan bahwa elemen utama dari pemberdayaan adalah pengembangan kapasitas masyarakat itu sendiri. Rangkaian pengembangan kapasitas dalam beberapa kegiatan pemberdayaan seperti PNPM Mandiri Perkotaan yang terdiri dari kegiatan sosialisasi, pelaksanaan siklus, dan pelatihan di Desa Sastrodirjan telah dijalankan dengan baik, dengan menggunakan pendekatan sosio-kultural yaitu dengan memperhatikan aspek keagamaan, aspek gender dan kebiasaan sehari-hari masyarakat (Bambang, Dwiyanto, \& Jemadi, 2013).

c) Diketahui bahwa nilai signifikan variabel X3 (Fasilitator Pemasaran) berada pada nilai sig. 0,857 , yang berarti bahwa nilai sig $>\alpha$, sehingga $\mathrm{H}_{0}$ diterima dan $\mathrm{H}_{1}$ ditolak. Dapat disimpulkan bahwa variabel X3 (Fasilitator Pemasaran) tidak berpengaruh secara signifikan terhadap variabel $\mathrm{Y}$ (Pemberdayaan) secara parsial.

Peran koperasi sebagai fasilitator pemasaran dalam upaya pemberdayaan petani kopi berpengaruh negatif dan tidak signifikan. Petani merasa terbantu dengan peran koperasi sebagai fasilitator pemasaran . Tidak hanya memasarkan, namun juga mampu menawarkan harga yang cukup tinggi untuk membantu menampung hasil produksi usaha tani kopi di Kecamatan Ulu Pungkut.

Tingginya nilai peran serta koperasi sebagai fasilitator pemasaran dalam upaya pemberdayaan petani kopi dengan berbagai indikator yang sudah berjalan seutuhnya dan dinilai berimplikasi cukup tinggi dalam memberdayakan masyarakat yakni beberapa indikator peran dimana koperasi membantu menampung hasil pertanian, mencapai pasar baru, ikut membantu dalam mempromosikan produk, dan terlibat dalam berbagai pameran ternyata bernilai negatif terhadap nilai pemberdayaan. Hal itu terjadi dikarenakan kurangnya kesadaran dan pemahaman petani kopi mengenai pemasaran hasil produksi dan terbuai karena terus difasilitasi tidak berjalan secara bersama namun hanya berat di sisi peran koperasinya saja.

d) Diketahui bahwa nilai signifikan variabel $\mathrm{X} 4$ (Fasilitator Permodalan) berada pada nilai sig. 0,179 , yang berarti bahwa nilai sig $>\alpha$, sehingga $\mathrm{H}_{0}$ diterima dan $\mathrm{H}_{1}$ ditolak. Dapat disimpulkan bahwa variabel X4 (Fasilitator Permodalan) tidak berpengaruh secara signifikan terhadap variabel Y (Pemberdayaan) secara parsial.

Koperasi Mandailing Jaya saat ini belum memiliki pelayanan kegiatan simpan pinjam, karena fokus awalnya adalah pengembangan usaha tani melalui penguatan individu dan kelompok terlebih dalam sektor pemasaran. Namun, kedepannya peran lembaga koperasi sudah merencanakan adanya realisasi mengenai pemberian modal simpan pinjam untuk mendukung pengembangan agribisnis kopi di Kecamatan Ulu Pungkut.

e) Diketahui bahwa nilai signifikan variabel X5 (Motivator) berada pada nilai sig. 0.048, yang berarti bahwa nilai sig. $<\alpha$, sehingga $\mathrm{H}_{0}$ ditolak dan $\mathrm{H}_{1}$ diterima. Dapat disimpulkan bahwa variabel X5 (Motivator) memberikan pengaruh secara signifikan terhadap variabel $\mathrm{Y}$ (Pemberdayaan) secara parsial. 
Peran koperasi sebagai motivator usaha dapat mendukung secara positif nilai dari pemberdayaan masyarakat namun nyatanya SDM menjadi slah satu kunci utama sebagai sasaran yang akan diberdayakan, ketika program sudah berjalan sebagaimana mestinya seharusnya SDM juga bergerak seiringan. Namun kecendrungan sifat dari manusia itu sendiri dapat mengurangi nilai yang sudah bagus dan begerak kearah yang berlawanan dan menimbulkan sifat yang malas, saling ketergantungan terhadap koperasi, hanya mengandalakan koperasi, dan tidak mau partisipatif merencanakan program kegiatannya untuk mengatasi permasalahan yang ada.

Proses pelaksanaan peran sebagai motivator kerap terjadi secara langsung dan tidak terjadwal, yang berperan sebagai motivator adalah anggota koperasi yang sudah paham mengenai tata laksana usaha di setiap subsektornya, sasarannya adalah petani yang menjadi anggota ataupun masyarakat yang bukan anggota bebas diperbolehkan datang dan melakukan konsultasi di kantor koperasi untuk mendapatkan arahan solusi dan pemecahan masalah mengenai permasalahan yang dihadapi.

Terjadinya proses pemberdayaan masyarakat salah satu kriterianya adalah terjadinya peningkatan kualitas SDM. Paradigma masyarakat yang konservatif masih takut untuk mencoba dan malas mencari wawasan baru. Beberapa hal ini jugalah yang terjadi di lokasi penelitian yang bisa menjadi sebab berubahnya nilai peran lembaga koperasi sebagai motivator mempengaruhi nilai terhadap nilai pemberdayaan walau cenderung rendah (Rahmi \& Agustiyani , 2018).

\section{KESIMPULAN}

Peran Koperasi Mandailing Jaya dalam Pemberdayaan Petani Kopi diperoleh kesimpulan sebagai berikut.

1. Tingkat peran koperasi Mandailing Jaya dalam upaya pemberdayaan petani kopi di Kecamatan Ulu Pungkut Kabupaten Mandailing Natal memperoleh nilai persentase yang cukup tinggi yaitu sebesar 52,90 persen sehingga mendukung untuk dapat melaksanakan pengembangan peran koperasi dalam pemberdayaan petani.

2. Secara simultan peran Koperasi Mandailing Jaya berpengaruh nyata terhadap upaya pemberdayaan petani kopi kopi di Kecamatan Ulu Pungkut Kabupaten Mandailing Natal, sedangkan secara parsial peran Koperasi Mandailing Jaya dalam upaya pemberdayaan petani kopi beberapa variabel memberikan pengaruh yang signifikan diantaranya peran Koperasi Mandailing Jaya sebagai mitra usaha, pemberi pelatihan, dan motivator, sedangkan variabel yang tidak berpengaruh adalah fasilitator pemasaran dan fasilitator permodalan.

Berdasarkan kesimpulan diatas, maka saran yang dapat penulis sampaikan adalah:

1. Perlu dilakukannya penguatan lembaga koperasi terlebih dahulu baik dari segi modal, konsep pengembangan usaha, agar lebih bisa memberikan dampak yang lebih besar terhadap upaya pemberdayaan petani kopi di Kecamatan Ulu Pungkut Kabupaten Mandailing Natal

2. Perlunya meningkatkan kesadaran petani dan masyarakat akan pentingnya berkoperasi guna dapat meningkatkan produktivitas dan taraf hidup masyarakat di daerah penelitian bisa dengan pelaksanaan kegiatan penyuluhan, pelatihan dan berbagai kegiatan lainnnya

3. Diperlukannya penelitian lebih lanjut agar dapat diketahui variabel lain dalam peran koperasi serta apa saja yang dapat mempengaruhi nilai pemberdayaan petani kopi di Kecamatan Ulu Pungkut Kabupaten Mandailing Natal.

\section{Daftar Pustaka}

Bambang , S., Dwiyanto, \& Jemadi. (2013). Pemberdayaan Masyarakat dan Pengembangan Kapasitas Dalam Penanggulangan Kemiskinan Melalui PNPM Mandiri Perkotaan. Jurnal Maksipreneur.

Dinas Pertanian Kabupaten Mandailing Natal. (2015). Pertaniandan Perkebunan Kabupaten Mandailing Natal Dalam Angka.

Direktorat Jendral Kekaya an Intelektual Kementerian Hukum dan HAMRI. (2016). Indeks Geografis Kopi Provinsi Sumatera Utara. Jakarta. 
Ghoza li, I. (2016). Aplikasi Analisis Multivariete Dengan Program IBM SPSS 23 (Edisi 8). Cetakan ke VIII. Sema rang: Badan Penerbit Universitas Diponegoro.

Nurhayati, \& Hadis, A. (2010). Psikologi dalam Pendidikan. Bandung: Alfabeta.

Purba, R. P., Bakti, D., \& Sitepu , S. F. (2015. ). Hubungan Persentase Serangan Dengan Estimasi Kehila ngan Hasil Akibat Sera ngan Hama Penggerek Buah KopiHypothenemus hampeiFerr. (Cole optera : Scolytidae) di Kabupaten Simalungun. Jurnal Online Agroekoteknologi,, 790-799.

Putra , H., \& Natsir, M. (2015). Analisis Faktor-Faktor Yang Mempengaruhi Produksi Sektor Pertanian Di Propinsi Aceh. Agrisep.

Rahmi , \& Agustiyani . (2018). Faktor-faktor yang Mempengaruhi Status Kemiskinan Pekerja di Indonesia (Analisis Data Susenas dan Sakernas 2008). Depok: Pascasarjana Universitas Indonesia.

Riduwan, \& Sunarto. (2014). Pengantar Statistika untuk Penelitian: Pendidikan, Sosial, Komunikasi, Ekonomi dan Bisnis. Bandung: Alfa beta.

Sugiyono. (2016). Metode Penelitian Kuantitatif, Kualitatif dan $R \& D$. Bandung: PT Alfabet.

Sugiyono. (2016). MetodePenelitian Kuantitatif, Kualitatif dan $R \& D$. Bandung: PT Alfabet. 